\author{
Gehrels WR, Anderson, William (2014) Reconstructing Holocene sea-level change from coastal \\ freshwater peat: A combined empirical and model-based approach, Marine Geology 353:140-152. \\ Version of record available from [ISSN: 0025-3227], [DOI: 10.1016/margeo.2014.04.004.
}

\title{
Reconstructing Holocene sea-level change from coastal freshwater peat: A combined empirical and model-based approach
}

A B S T R A C T

\begin{abstract}
This paper presents a novel method to reconstruct sea-level change in coastal freshwater back-barrier marshes. Freshwater environments have long been considered to be unsuitable for the reconstruction of Holocene sea-level changes as they provide limiting, rather than precise, sea-level index points. We recorded the stratigraphy of a small beach and back-barrier coastal Phragmites (reed) marsh at Hallsands, south Devon, southwest England, using hand-drilled cores and ground-penetrating radar, and collected five new sea-level index points from the base of a Holocene peat sequence to refine the regional Holocene relative sea-level curve. We demonstrate that the samples, despite their freshwater origin, yield accurate sea-level index points as determined from the quantifiable relationship between tide levels and groundwater. By means of water-table monitoring and ground-water modelling we show that the primary controls on the water table in the marsh are: (1) stratigraphy; (2) peat permeability; and (3) recharge rates in the back-barrier marsh. The five index points document relative sea-level positions between 7200 and $2400 \mathrm{cal} \mathrm{yr} \mathrm{BP.} \mathrm{Three} \mathrm{points} \mathrm{are} \mathrm{in} \mathrm{good} \mathrm{agreement} \mathrm{with} \mathrm{previously} \mathrm{collect-ed} \mathrm{regional} \mathrm{data} \mathrm{from}$ intertidal deposits and two points usefully fill gaps in the existing reconstruction. An amended Holocene relative sea-level curve for south Devon, based on 30 data points, is presented. We conclude that the combined approach of data collection and modelling used in this paper can be applied to similar coastal settings around the world and allows the collection of sea-level index points from locations not previously thought suitable for this purpose.
\end{abstract}

\section{Introduction}

Reconstructions of Holocene relative sea-level change are commonly presented in time-altitude graphs in which ages that are plotted against vertical position are known as sea-level index points. These points are derived from samples obtained from clastic coastal sediments or peat and to qualify as a bona fide sea-level index point must have an age (i.e. the associated samples were dated by radiocarbon or other methods) and a known elevation at which the dated materials were formed (Shennan, 1986; Shennan et al., in press). This elevation is measured relative to a tidal datum (e.g., mean sea level, or mean high water) and is known as the 'indicative meaning' of the sea-level index point (van de Plassche, 1986; Shennan et al., in press). Both the age and indicative meaning are associated with uncertainties that are presented as horizontal and vertical error bars of the sea-level index points so that these index points are usually shown as crosses (Parnell and Gehrels, in press). There are three main types of sea-level index points (Shennan and Horton, 2002; Engelhart and Horton, 2011). The most reliable index points are derived from basal peat or basal coastal sediments formed at the base of the
Holocene sedimentary section, directly overlying a hard substrate, usually sand or rock. Basal index points cannot have been significantly displaced by the process of sediment consolidation. Of lesser quality than the basal points are those index points obtained from within thick Holocene clay and peat sequences. These are known as intercalated index points and are less reliable because the sediments from which they are derived have been consolidated by the weight of overlying sediments. A third category of sea-level index points consists of those that are 'limiting'. Many of these are derived from freshwater organics (such as fen peat) that formed above the highest tide level, at an unknown vertical position above mean sea level. Limiting index points can also come from marine sediments that formed some unknown distance below the lowest tide level.

Back-barrier systems are recognised as suitable environments for reconstructions of Holocene sea-level change. Sea-level index points have been almost exclusively collected from intertidal sediments in systems that have (or had) an open connection to the sea via a tidal inlet (e.g., Redfield and Rubin, 1962; van de Plassche et al., 1989; Healy, 1995; Kelley et al., 1995; Gehrels et al., 1996; Donnelly, 2006; Sloss et al., 2007; Massey et al., 2008). The water-level history in these open systems is not only controlled by sea-level movements, but also by morpho-dynamical and sedimentary processes. Significant reworking 
of sediments takes place through processes such as channel meandering and bank erosion (Kelley et al., 2000) and, as a result, sea-level index points can be widely scattered when plotted in a time-altitude diagram (Healy, 1995; Sloss et al., 2007; Massey et al., 2008). In closed backbarrier systems, on the other hand, dynamical processes can be ruled out.

A potential problem is that under freshwater conditions in closed barrier systems the water table may be controlled by factors such as rainfall and sediment permeability. In this paper we show that in small coastal barrier systems sea-level index points can be highly accurate because the water table in the back-barrier marsh is directly controlled by sea level. We present new sea-level index points for southwest England, derived from freshwater coastal peat, that are precise and not limiting. We calculate with a numerical model the conditions that are required for peat growth to be directly controlled by tidal movements, thus facilitating the application of our method in similar back-barrier systems elsewhere in the world. We show that, on longer time scales, sea-level rise generates vertical peat growth in these systems and small back-barrier coastal freshwater marshes therefore contain valuable archives from which Holocene sea-level change can be reconstructed.

\section{Study site and field methods}

Our study site is located on the English Channel coast at Hallsands in south Devon, southwest England, where a 250-m-long shingle barrier protects a small freshwater valley marsh (Fig. 1). The vegetation of the marsh is dominated by common reed (Phragmites communis) wit h o c c a - sional alder trees (Alnus glutinosa). The mean spring tidal range along this part of the Channel coast is $4.4 \mathrm{~m}$ and the tides are semi-diurnal. The transgressive nature of the barrier system is evident from periodic exposuresoffossilpeatandalder

treestumpsonthebeachfacefollowing periods of erosion (Fig. 2). The Hallsands barrier is susceptible to erosion

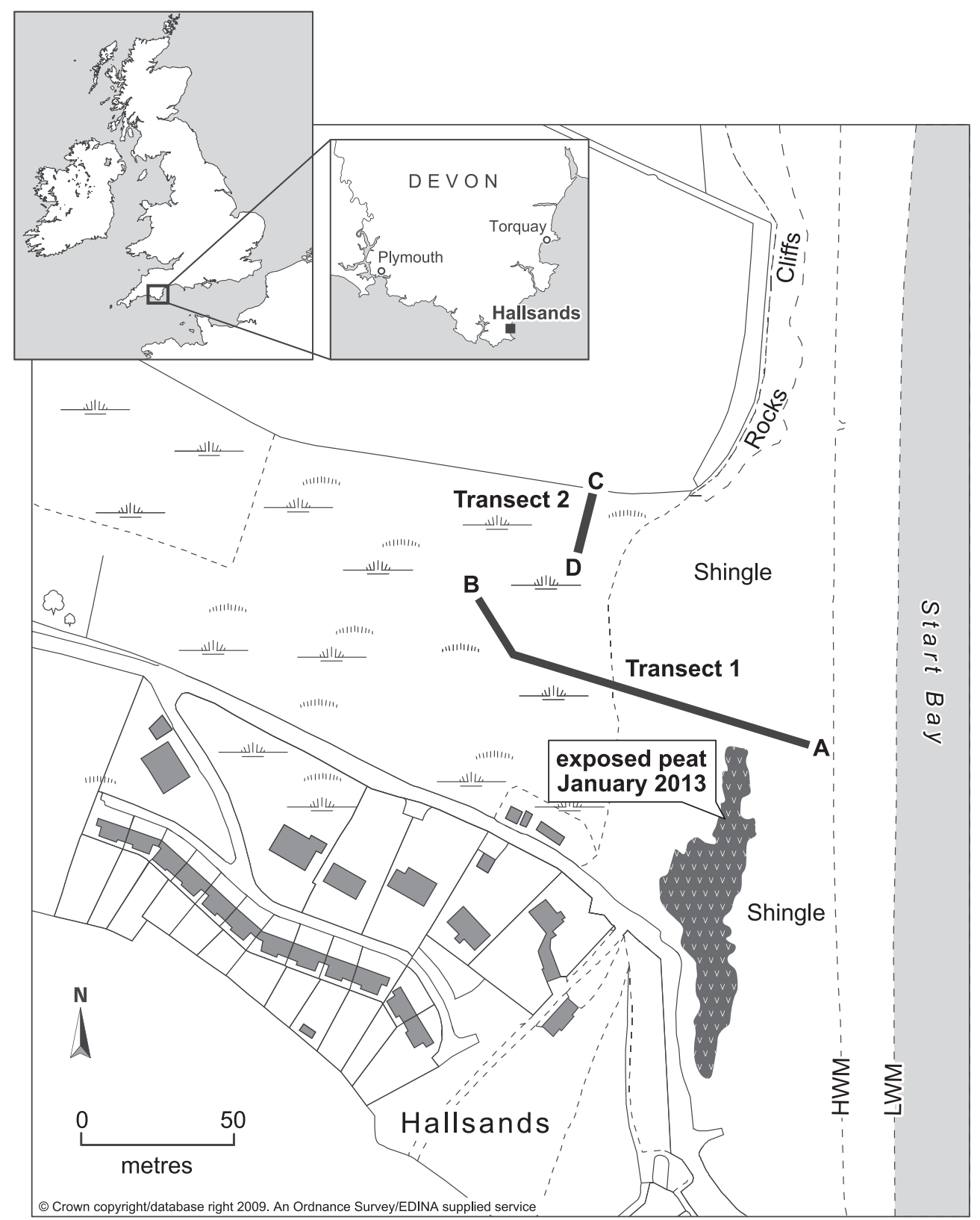

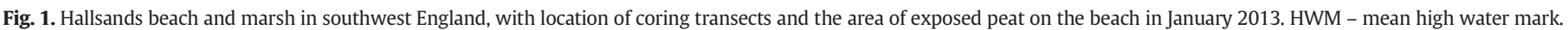
LWM - mean low water mark. 


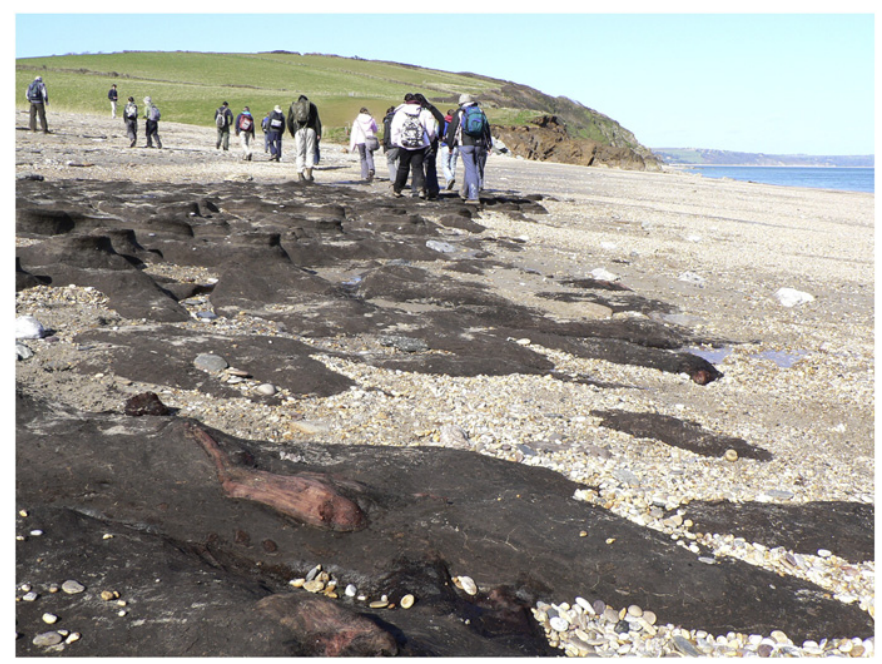

Fig. 2. Phragmites peat and fossil Alnus stumps exposed on the beach at Hallsands in March 2007.

andoverwashduringlongspellsofeasterlywindsw hen gravel is depos-ited across the barrier crest onto the backbarrier marsh (Fig. 3). The last two of such erosive episodes were in March 2007 and January 2013. One of the fossil tree stumps provided one of the first sea-level index points for this region; it was dated in the early 1970 s to $1683 \pm 40{ }^{14} \mathrm{C}$ y r B P (Morey, 1983). The date features in reviews of relative sea-level changes around the British Isles by Shennan and Horton (2002), Shennan et al.(2006) and Kuchar et al. (2012), but was considered unreliable as a sea-level index point by Gehrels (2006) owing to the imprecise nature of the indicator (a tree stump).

We cored the freshwater marsh with an Eijkelkamp gouge auger to document the stratigraphy. The sequences consist almost entirely of organic deposits, with no evidence of any tidally influenced minerogenic deposition. We installed monitoring wells in two of the boreholes with $1.5 \mathrm{~m}$ of PVC casing and slotted screen. We used a PulseEkko ground-penetrating radar (GPR), with $100-\mathrm{mHz}$ antennae, to establish the thickness of the shingle beach. Its thickness was also determined from a survey of the underlying peat when it was exposed in January 2013. Radiocarbon dating of plant macrofossils was conducted by Beta Analytic (Miami, Florida, USA). We measured water-table variations in two monitoring wells in the marsh installed at 5 and $25 \mathrm{~m}$ from

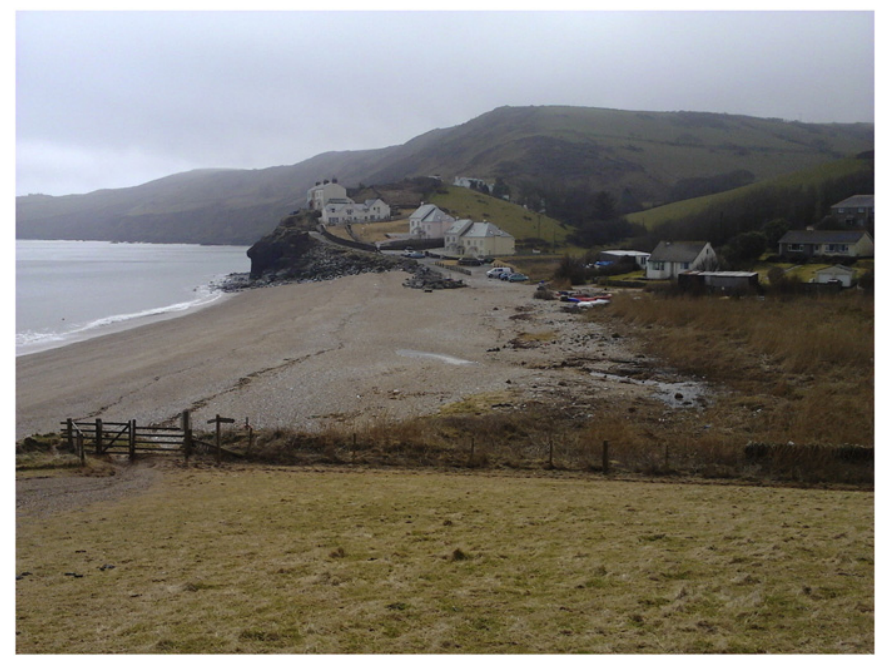

Fig. 3. Washover gravel in the marsh behind the Hallsands barrier in April 2013. the marsh-beach transition. All water-level data were recorded at ten-|minute intervals using In-Situ Level TROLL 500 pressure transducers, logging data for six months. Surveys were conducted using a Total Station and Differential Global Positioning System and all heights were tied to the UK geodetic datum (Ordnance Datum).

\section{Groundwater modelling}

Numerical simulations use the US Geological Survey's coupled groundwater flow - solute/heat transport finite-element code SUTRA (Saturated-Unsaturated TRAnsport) (Voss, 1984; Voss and Provost, 2002). SUTRA has been applied to many coastal aquifer studies (e.g., Li et al., 2000; Robinson et al., 2007; Anderson and Lauer, 2008; Anderson and Emanuel, 2010). The model domain (Fig. 4) depicts a shore-perpendicular cross section that extends $75 \mathrm{~m}$ offshore and below neap low tide and extends $100 \mathrm{~m}$ from the barrier into the freshwater marsh. The model domain comprises 11044 nodes and 10750 elements. Nodes are spaced at $1-\mathrm{m}$ intervals horizontally and are spaced $0.25-0.07 \mathrm{~m}$ apart vertically.

We simplified the hydrostratigraphy to a peat-gravel barrier aquifer system. See Table 1 for hydraulic properties used in the simulation of the base case. The horizontal permeability of the gravel unit derives from grain-size distribution and the vertical permeability is calculated using equivalent permeabilities of a two-layer case (there are two distinct grain-size populations in the gravel). The peat permeabilities are determined in part from tidal efficiencies measured in monitoring wells installed in the peat. The model-calibration process systematically adjusted the peat permeabilities to best fit the empirical data. In all simulations, porosity was set to a constant 0.20 with a model thickness into the cross section of $1 \mathrm{~m}$.

Table 1 shows the calibrated parameters for the base model that provided the best fit to the Hallsands field data. The calibration process involved two steps. First, grain-size distribution data from the gravel beach were used in the Hazen Method to provide a rough estimate of permeability. Next, these data were combined with estimates of peat permeability to calculate an equivalent permeability based on the best fit to tidal-efficiency data at monitoring well MW-5. Given the broad range in the distance of MW-5 from the high tide line throughout the tidal cycle and the variable thickness of the two layers, these rough estimates of $2 \times 10^{-14}$ and $3.2 \times 10^{-10} \mathrm{~m}^{2}$ in the peat and gravel layers, respectively, provide a starting point for model calibration with SUTRA but not a definitive value. Calibration simulations began with these parameters, but they were varied in conjunction with recharge rates until the best fit to mean water-table elevations and tidal efficiencies was obtained. As the data in Table 1 indicate, the initial estimates of permeability were close to the final calibrated values, especially for the gravel estimates.

Boundary conditions include no-flow boundaries at the edges and base of the aquifer, whilst tidally oscillating water levels were applied to the appropriate cells of the beach using tidal data collected at Slapton four kilometres to the north of the site. An analytical solution for the tidal oscillation based on the first five harmonics that best fit the Slapton tidal data was used to apply a tidally oscillating coastal boundary condition that best resembled the field conditions at Hallsands. The simulations do not account for variations in predicted tidal oscillations due to wind and storms. Constant freshwater salinities of $0.0 \mathrm{~kg} / \mathrm{kg}$ were applied to the left boundary and the freshwater marsh of the model domain. Constant seawater salinities of $0.0357 \mathrm{~kg} / \mathrm{kg}$ were applied to the upper (seabed) boundary below low tide and to the gravel along the seaward edge of the model domain. Constant recharge rates of $0.30 \mathrm{~m}$ per year and $0.50 \mathrm{~m}$ per year were applied to the peat and gravel, respectively, with all recharge water at zero concentration. Recharge to the gravel occurs only above the maximum tidal level. Simulations run from a cold start using 30 second time steps. Simulations were run for 50 full spring-neap-spring-neap tidal cycles or 1476 days. 


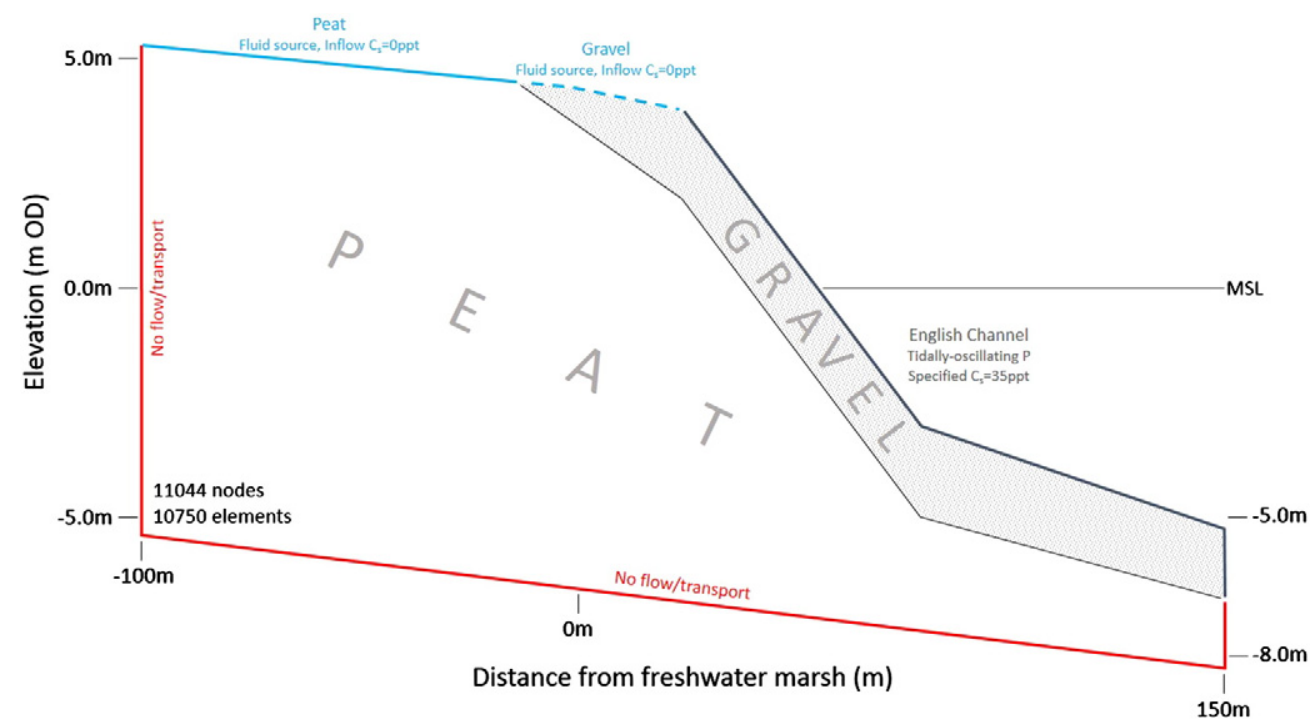

Fig. 4. Model domain for the simulations performed in this study. The figure shows a shore-normal cross section that is $250 \mathrm{~m}$ in width and of variable height.

\section{Results}

\subsection{Lithostratigraphy}

We collected 19 cores along two transects in the freshwater marsh (Fig. 1). Transect 1 is a shore-normal cross section that also includes parts of the beach (Fig. 5). Our deepest core, $50 \mathrm{~m}$ from the beach, terminated on bedrock at $11 \mathrm{~m}$ depth below the surface. A hazelnut from the base of this core returned an age of $6290 \pm 40 \mathrm{BP}$. The recovered facies are all distinctly organic and include peaty mud with a layer of wood (alder) peat in the lower section and a top layer of Phragmites peat. Within the Phragmites peat we encountered some beach pebbles and a gravelly clay layer that is similar in composition to the Pleistocene solifluction diamicts ('head'; De La Beche, 1839) that cover the hill slopes and fill the valleys along much of the coast of southwest England. This clay unit was exposed on the berm crest in January 2013. The surface of the beach in Fig. 5 represents its summer profile as determined from a GPR survey in June 2011. The lithostratigraphic units found along core Transect 1 were also encountered along the shore-parallel Transect 2 (Fig. 6). The clay unit was interpreted as slope wash (remobilized 'head') based on its increased thickness near the valley side. Four

Table 1

Hallsands groundwater model base case parameters.

\begin{tabular}{|c|c|}
\hline Parameter & Value \\
\hline \multicolumn{2}{|l|}{ Peat properties } \\
\hline Maximum permeability $\left(\mathrm{m}^{2}\right)$ & $7.0 \times 10^{-14}$ \\
\hline Minimum permeability $\left(\mathrm{m}^{2}\right)$ & $3.0 \times 10^{-14}$ \\
\hline Recharge $^{*}(\mathrm{~kg} / \mathrm{s})$ & $8.56 \times 10^{-4}$ \\
\hline \multicolumn{2}{|l|}{ Gravel properties } \\
\hline Maximum permeability $\left(\mathrm{m}^{2}\right)$ & $5.0 \times 10^{-11}$ \\
\hline Minimum permeability $\left(\mathrm{m}^{2}\right)$ & $1.0 \times 10^{-11}$ \\
\hline Recharge $^{* *}(\mathrm{~kg} / \mathrm{s})$ & $8.75 \times 10^{-4}$ \\
\hline \multicolumn{2}{|l|}{ Both model layers } \\
\hline Porosity & 0.20 \\
\hline Longitudinal dispersivity in maximum permeability direction (m) & 0.30 \\
\hline Longitudinal dispersivity in minimum permeability direction (m) & 0.03 \\
\hline Transverse dispersivity in maximum permeability direction (m) & 0.03 \\
\hline Transverse dispersivity in minimum permeability direction (m) & 0.03 \\
\hline Model thickness (m) & 1.0 \\
\hline
\end{tabular}

radiocarbon dates were obtained from Transect 2 on plant remains found at the base of the Holocene section.

\subsection{Groundwater monitoring}

Water-table elevation and temperature time series for monitoring wells MW-5 and MW-25 are shown in Fig. 7. MW-5 lies $5 \mathrm{~m}$ into the freshwater marsh and has a $1.5-\mathrm{m}$ screen that is open partially to gravel and partially to slope wash and peat. MW-25 lies $25 \mathrm{~m}$ into the marsh and has a $1.5-\mathrm{m}$ screen that is completely within peat and slope wash. See Fig. 5 for the stratigraphy at the position of each of these wells, which in the figure are located at distances of -5 a n d $-25 \mathrm{~m}$. As was expected, the water table at MW-25 is higher than that measured in MW-5, suggesting that the regional gradient, and groundwater flow, in the marsh are seaward. The water-level data also show that recharge of the freshwater marsh is efficient. This is not surprising at MW-5, which has highly permeable gravel at the surface. The recharge at MW-25, though muted compared to MW-5, is higher than expected. Water-table variations at MW-25 are, in most cases, approximately $40 \%$ of those at MW-5, which reach $0.5-\mathrm{m}$ of variations during recharge events.

The water-table time series show seasonal effects as well. Lower recharge rates in summer due to higher evapotranspiration and poten-tially lower precipitation produce relatively low water-table elevations in both wells, averaging approximately 3.7 and $4.3 \mathrm{~m}$ OD at MW-5 and MW-25, respectively (Fig. 7a). By early autumn, evapotranspiration rates fall, recharge rates increase, and water-table elevations rise dramatically to average 4.2 and $4.6 \mathrm{~m}$ OD at MW-5 and MW-25, respec-tively. Water levels in MW-25 throughout winter show very limited oscillations, which suggests that the relatively low permeability of the peat is allowing water storage and the marsh sediments are fully satu-rated. Water-table elevations are less consistent in the winter months at MW-5 owing to the influence of the highly permeable gravel layer, which recharges easily but also efficiently transmits groundwater to the English Channel between storm events. The temperature time series in Fig. 7b also display seasonality. Temperatures in MW-5 are higher in summer and lower in winter than they are in MW-25, with seasonal variations of approximately 8 and $5{ }^{\circ} \mathrm{C}$, respectively, suggesting that groundwater at MW-5 is more closely influenced by atmospheric condi-tions than it is at MW-25. Again, this reflects the higher recharge rates and higher permeability that this part of the marsh experiences owing to the presence of gravel. 


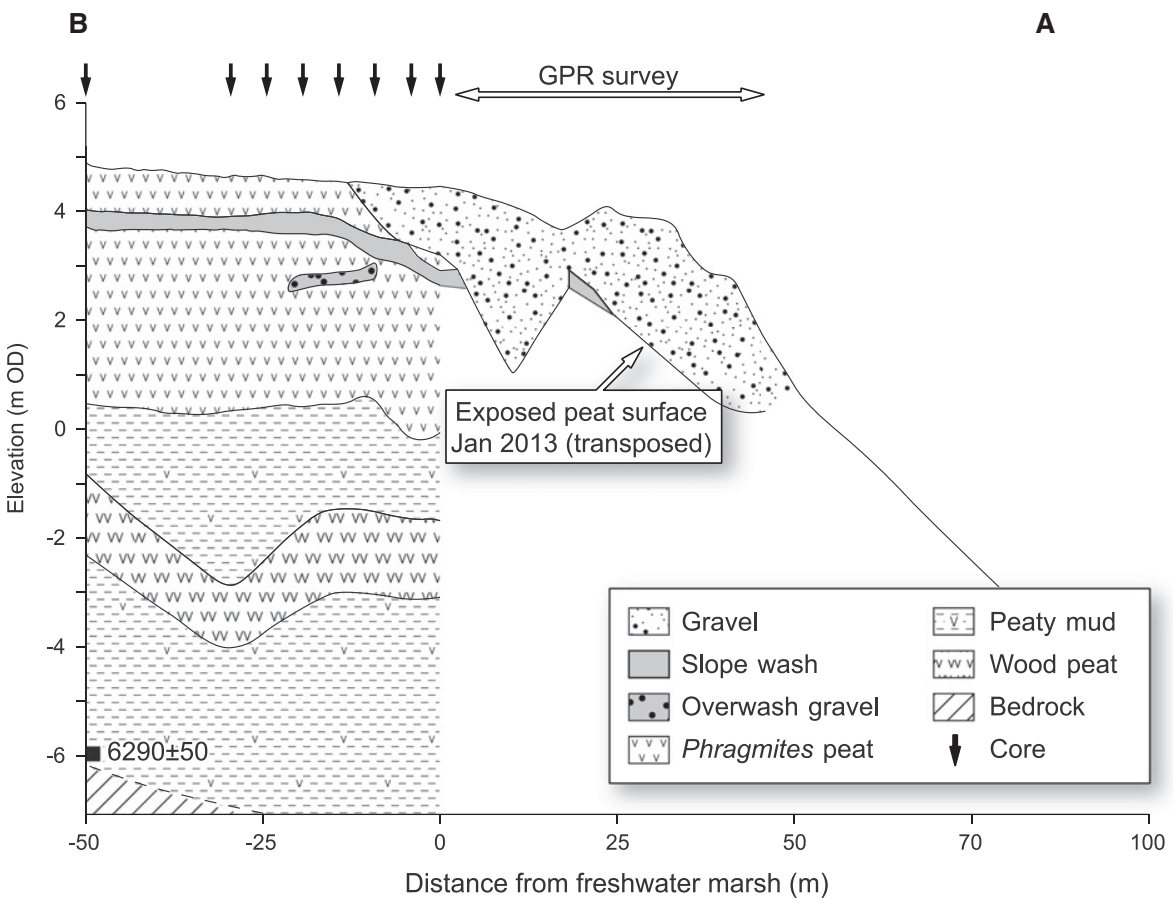

Fig. 5. Shore-normal stratigraphic Section 1. S e e Fig. 1 for location.

Groundwater level in the vicinity of MW-5 also displays tidal oscillations. Spectral analyses of the water-table time series are compared with tidal oscillations at Slapton, $4 \mathrm{~km}$ to the north of Hallsands, in Fig. 8. The tidal data (Fig. 8a) show peak variance at frequencies of approximately 1,2 , and 3.8 per day. These same peaks are observed in the MW-5 time series, although the variance is not as high and the peaks are not as distinct (Fig. 8b). This is expected given the complexity of the hydrostratigraphy and the noise in the signal in addition to the large difference in the tidal amplitudes between those measured in the English Channel (up to $2.5 \mathrm{~m}$ ) and the monitoring well (on the

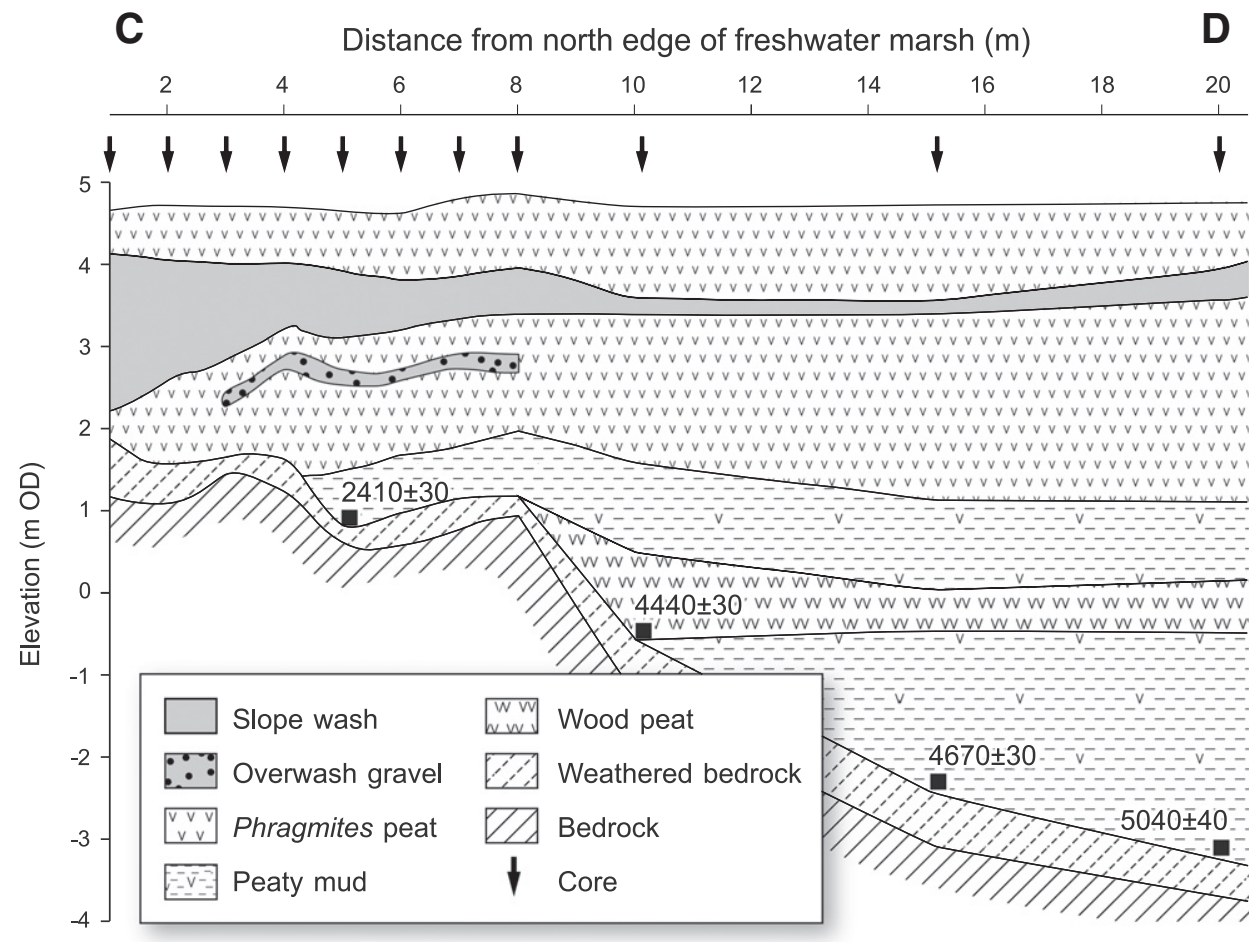

Fig. 6. Shore-parallel stratigraphic Section 2. S e e Fig. 1 for location. 
(a)

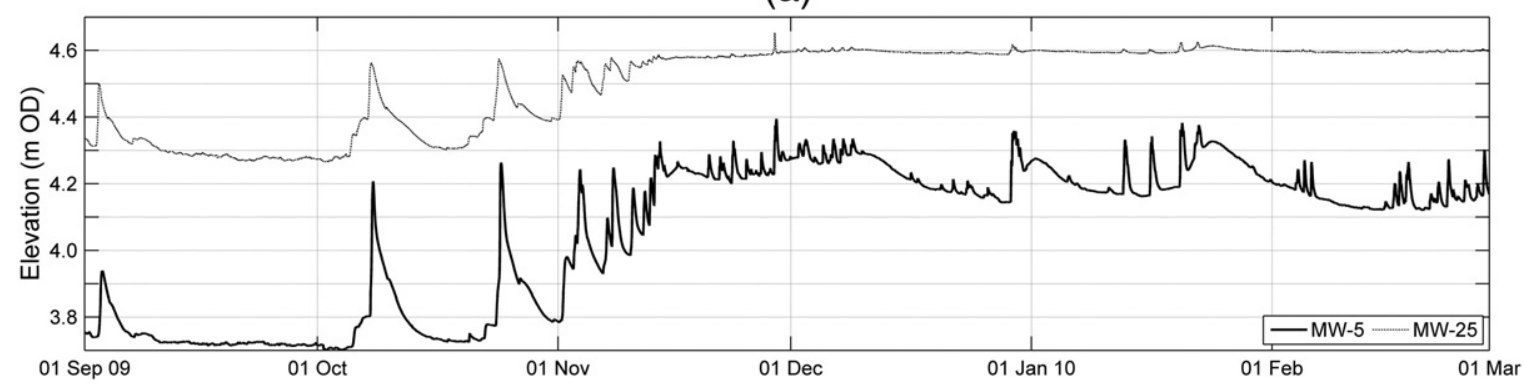

(b)

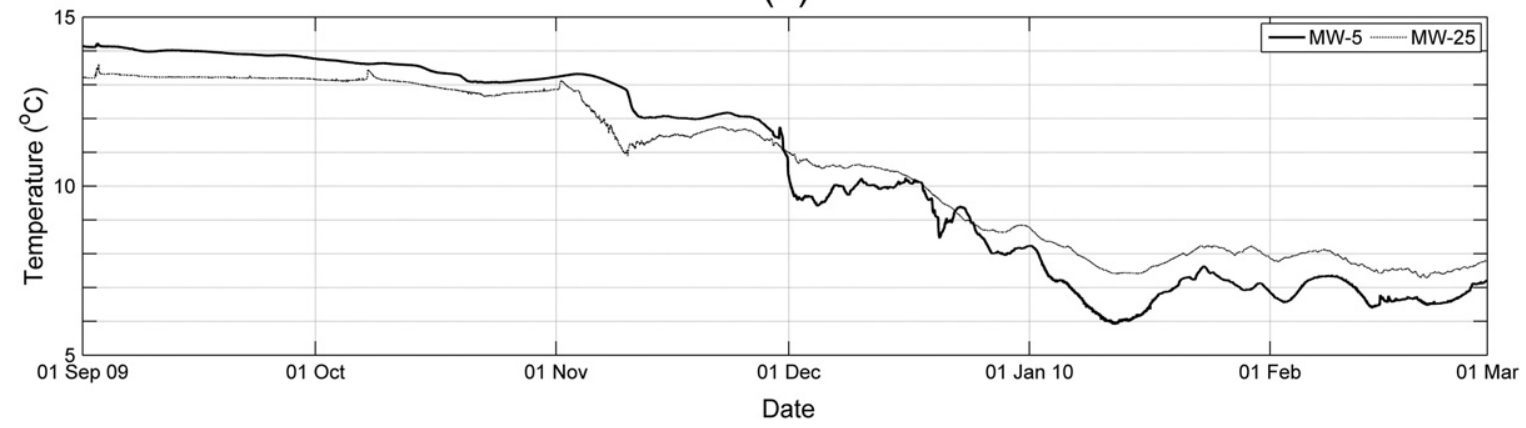

Fig. 7. Water-table elevation (a) and groundwater temperature (b) time series for MW-5 (solid line) and MW-25 (dot-dash line).

order of a centimetre). There is no discernible variance peak in the spectral analysis of the MW-25 data, most likely because of signal filtering by the relatively low-permeability peat.

\subsection{Relationship of the local water table to sea level}

Our observations show that a tidal signal is present in the groundwater of the back-barrier marsh. This signifies that peat formation in the marsh is directly controlled by the sea-level boundary condition. If this has been the case throughout the history of the back-barrier marsh, then the accumulation rate of the peat can be used as a proxy for sealevel rise. The five new radiocarbon-dated samples thus potentially provide accurate basal sea-level index points, not affected by vertical displacement through sediment consolidation, if their indicative meaning can be established with sufficient precision. In this section we assume in the first instance that uniformitarian principles apply and that the

(a)

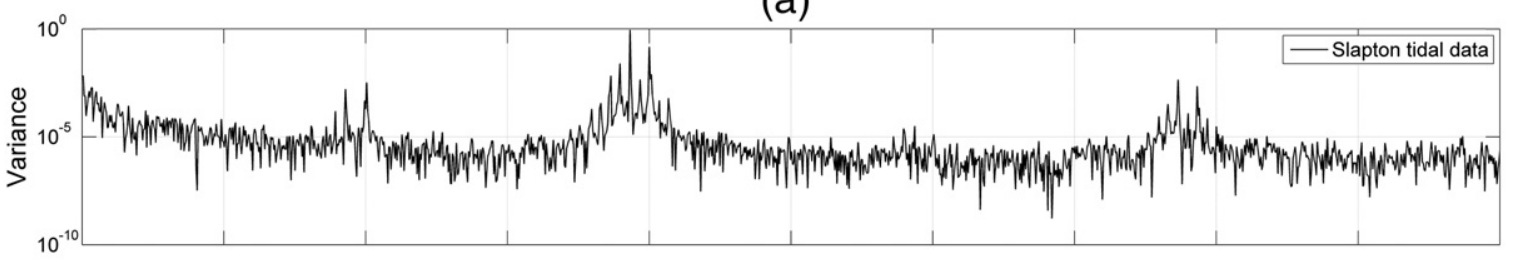

(b)

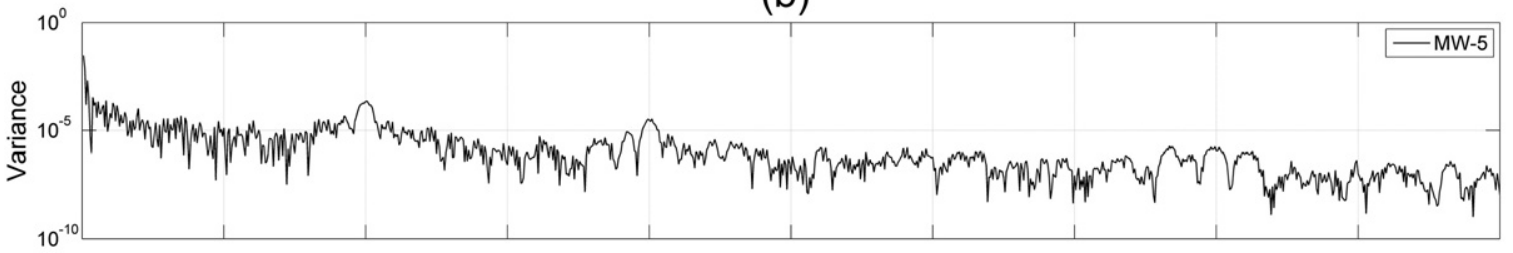

(c)

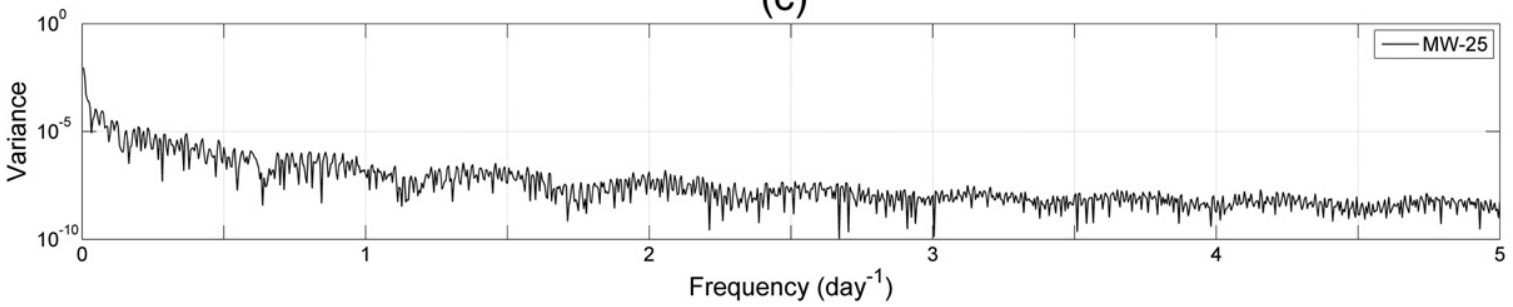

Fig. 8. Spectral analyses of tidal oscillations at Slapton, UK (a) and groundwater oscillations at MW-5 (b) and MW-25 (c). 
(a)

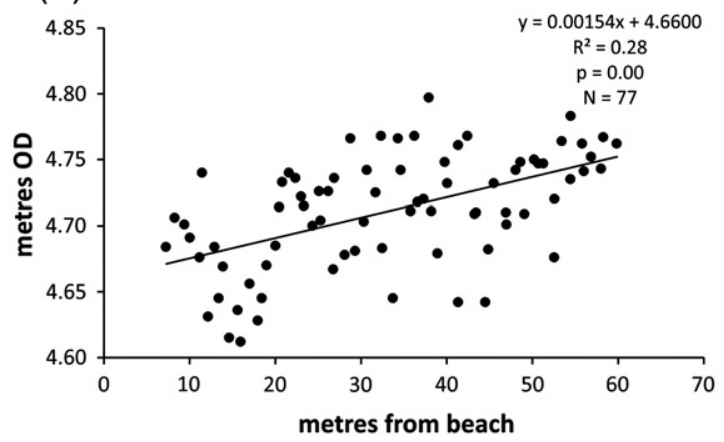

(b)

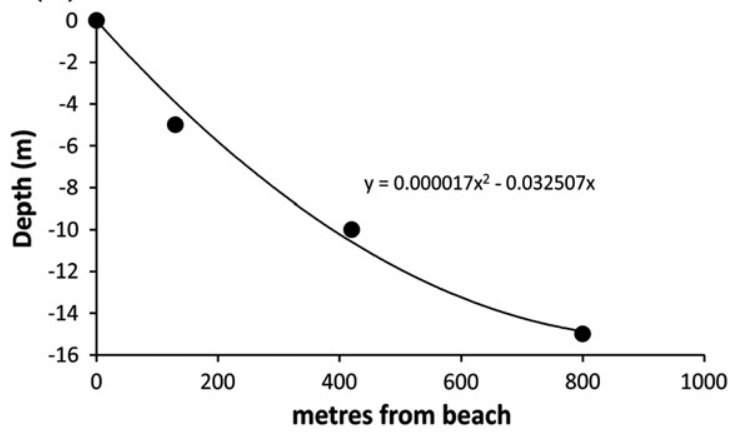

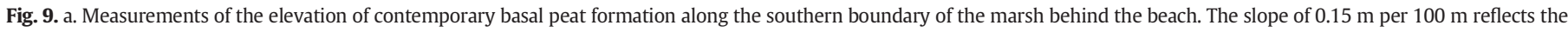

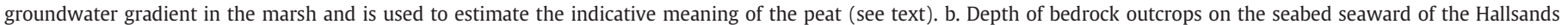
barrier. Measurements were taken from a bathymetric chart and are relative to Chart Datum.

groundwater regime in the back-barrier has remained unchanged. At the end of this section we will add some modifications to this assumption based on the stratigraphy of the marsh and the results of groundwater modelling.

The determination of the indicative meaning of the peat is complicated by the gradient of the water table that is present in the back-barrier environment. We calculated this gradient by measuring the longitudinal change in the height of the edge of the marsh where it laps onto the valley slope; this is the modern equivalent of the environment in which basal peats were formed. It should be noted that this approximation assumes a linear water-table gradient, which is not the case; however, we do think that this method provides a good estimation of the mean hydraulic gradient within the peat-gravel barrier. Because of the presence of this gradient of $0.15 \pm 0.04 \mathrm{~m}$ per $100 \mathrm{~m}$ (Fig. 9a) it is necessary to estimate how far the samples were formed behind the barrier. Also, sea level was lower in the past, so the barrier must have been seaward of its present position. To determine how far, we initially assumed an indicative mean-ing for each sample of $4.65 \mathrm{~m}$ (the average height of the edge of the marsh directly behind the barrier) and calculated its sea-level position (SL) using the relationship

$\mathrm{SL}=\mathrm{H}-\mathrm{I}$

where $\mathrm{H}$ is the height of the sample relative to Ordnance Datum and I is its indicative meaning (cf Gehrels, 1999). Because landward barrier migration has been a function of relative sea-level rise and bedrock gradient, we used the profile of the outcropping bedrock on the foreshore (Fig. 9b), read from bathymetric charts, to estimate the distance of the samples to the palaeobarrier and applied the groundwater gradient to calculate new values for I and SL. After three iterations the value of I did not change significantly and we adopted the value thus obtained as the initial estimate of the indicative meaning of the samples (Table 2 ). Using this procedure, the estimated distance from the land-ward edge of the palaeobarrier to the position in the marsh where the samples were formed ranged from $116 \mathrm{~m}$ for the youngest sample to $463 \mathrm{~m}$ for the oldest sample.

So far we have based our calculations on the assumption that the sealevel index points were collected from a Phragmites (reed) peat, formed in an environment identical to the back-barrier marsh today. However, four of our dated samples were collected from a peaty mud facies and one sample was collected from a woody peat. The increased mud content points to formation in a backbarrier environment marked by long periods of standing water. Although no stratigraphic evidence (e.g. gyttja) was found indicative of a permanent lake or pond, it must be assumed that the water table during the formation of the peaty mud facies may have been somewhat higher than today. In contrast, the growth of alder requires slightly drier conditions than are required for reeds. We assume, therefore, that peaty mud is formed when the water table is, on average, $0.2 \mathrm{~m}$ higher than when reeds thrive and that alder peat accumulates when the water table is, on average, $0.2 \mathrm{~m}$ lower. We also add an arbitrary

Table 2

Derivation of palaeosea-level estimates.

\begin{tabular}{|c|c|c|c|c|c|c|}
\hline & & \multicolumn{5}{|l|}{ Core } \\
\hline & & $\mathrm{T} 2-5$ & $\mathrm{~T} 2-10$ & $\mathrm{~T} 2-15$ & $\mathrm{~T} 2-20$ & $\mathrm{~T} 1-50$ \\
\hline & Height (m OD) & 4.72 & 4.69 & 4.75 & 4.75 & 4.75 \\
\hline & Depth in core (m) & 3.44 & 5.25 & 7.10 & 7.95 & 10.80 \\
\hline & Sample height (m OD) & 1.28 & -0.56 & -2.35 & -3.20 & -6.05 \\
\hline & Initial indicative meaning (m OD) & 4.65 & 4.65 & 4.65 & 4.65 & 4.65 \\
\hline \multirow[t]{3}{*}{ Iteration 1} & Shore distance $(\mathrm{m})$ & 112.43 & 178.09 & 251.49 & 287.91 & 428.06 \\
\hline & Indicative meaning correction $(\mathrm{m})$ & 0.17 & 0.27 & 0.39 & 0.44 & 0.66 \\
\hline & Sea level & -3.54 & -5.48 & -7.39 & -8.30 & -11.36 \\
\hline \multirow[t]{3}{*}{ Iteration 2} & Shore distance $(\mathrm{m})$ & 115.89 & 187.02 & 263.52 & 303.36 & 460.32 \\
\hline & Indicative meaning correction $(\mathrm{m})$ & 0.18 & 0.29 & 0.41 & 0.47 & 0.71 \\
\hline & Sea level & -3.54 & -5.50 & -7.40 & -8.32 & -11.41 \\
\hline \multirow[t]{4}{*}{ Iteration 3} & Shore distance $(\mathrm{m})$ & 116.08 & 187.55 & 264.31 & 304.43 & 463.27 \\
\hline & Indicative meaning correction $(\mathrm{m})$ & 0.18 & 0.29 & 0.41 & 0.47 & 0.71 \\
\hline & Indicative meaning ( $\mathrm{m} \mathrm{OD}$ ) & 4.83 & 4.94 & 5.06 & 5.12 & 5.36 \\
\hline & Sea level & -3.54 & -5.50 & -7.41 & -8.32 & -11.42 \\
\hline \multirow[t]{4}{*}{ Facies adjustment } & Indicative meaning correction $(\mathrm{m})$ & 0.20 & -0.20 & 0.20 & 0.20 & 0.20 \\
\hline & Indicative meaning ( $\mathrm{m} \mathrm{OD}$ ) & 5.03 & 4.74 & 5.26 & 5.32 & 5.56 \\
\hline & Sea level & -3.74 & -5.30 & -7.61 & -8.52 & -11.62 \\
\hline & Error & 0.34 & 0.34 & 0.34 & 0.34 & 0.34 \\
\hline
\end{tabular}

See text for explanation. 
error of $0.2 \mathrm{~m}$ to these estimates (Table 1 ). In the next section we explore the reasonability of our assumptions and use groundwater modelling to investigate the parameters that control the height of the water table in the marsh.

\subsection{Groundwater modelling}

The aim of the groundwater modelling is to understand the hydrogeologic conditions that would lead to the freshwater peat formation in the back-barrier marsh being a proxy for the Holocene sea-level history. If, in the past, the water table had been decoupled from sea level, then two different situations may have arisen. The first is the case where the water table is permanently elevated, resulting in ponding of the marsh and peat formation that is controlled mainly by local water-table conditions and insufficiently by the sea-level boundary condition. A second situation might arise if the water table drops below the root levels of the reeds and trees, resulting in drying out and oxidation of peat and a corresponding absence of time in the geologic record. We note that careful stratigraphic observations should be sufficient to address whether either of these situations should be taken into account.

Fig. 10 shows the results of base-case simulations of groundwater flow and solute transport within the peat-gravel barrier at low tide. The parameters for this set of simulations are shown in Table 1. It should be noted that these dynamic simulations are at quasi-steadystate at this time in the simulation period. Three important sets of model output (fractional seawater salinity, water-table profile and sea level at the time of simulation) and groundwater velocity vectors are shown in the cross section. The heterogeneity of the model domain, although simplified for these simulations, still has a significant effect on the subterranean estuary, which is the mixing zone between fresh and saline groundwater (Moore, 1999), making the peat-gravel aquifer system quite different from single-aquifer systems (Robinson et al., 2007). Rapid recirculation of seawater between high and low tides keeps the highly permeable gravel at near-seawater salinities (Austin et al., 2013). Freshwater circulation within the much less permeable peat attempts to create a freshwater discharge tube, but the rapid circula-tion of saline water within the gravel beach mixes with this discharging fresh water. Recharge rates coupled with the calibrated peat and gravel permeabilities keep the water table near the surface within the freshwa-ter marsh. Also, the large gradient at low tide keeps most of the groundwater circulation within the gravel beach, where large velocity vectors can be seen discharging at the low-tide line. The maximum groundwater velocity in the gravel is $3.4 \times 10^{-4} \mathrm{~m} / \mathrm{s}$, whereas circulation in the peat has groundwater velocities on the order $10^{-10} \mathrm{~m} / \mathrm{s}$. The maximum water-table elevation in the peat is $5.02 \mathrm{~m} \mathrm{OD}$.

We conducted model sensitivity experiments to document the response of the water-table profile to reductions in recharge rates. Simulations of reduced recharge rates in the peat to $75 \%$ (Fig. 11a) and $50 \%$ of the base recharge (Fig. $11 \mathrm{~b}$ ) were performed in order to test the overall influence of these reductions on the subterranean estuary. Although these reductions have a strong influence on the shape of the water table in the peat unit, they essentially produce no change in the shape of the subterranean estuary, which is much more controlled by tidal oscillations than by recharge rates. The fact that peak groundwater velocities in these simulations are the same as those under base-case conditions supports this assertion. Reductions in peat recharge rates lower the water table within the peat to maxima of $4.32 \mathrm{~m}$ and $3.62 \mathrm{~m}$ at $75 \%$ and $50 \%$ of base case recharge rates, respectively. Water-table elevations suggested by these simulations are far below the land surface and would likely cause the drying of reed and tree roots, thus leading to oxidation of the peat, as suggested earlier.

We also examined the sensitivity of the model to variations in the permeability of the beach and marsh sediments (Fig. 12). Variations of the gravel permeability by an order of magnitude above and below the base case permeability have little influence on water levels within the freshwater marsh, with water levels decreasing (to 4.96 $\mathrm{m} \mathrm{OD}$ ) or increasing slightly (to $5.40 \mathrm{~m} \mathrm{OD}$ ) with an increase of an order of magnitude (Fig. 12a) and a decrease of an order of magnitude (Fig. 12b), respectively. The peak velocity under the highpermeability condition is an order of magnitude higher than the base case simula-tion (velocity $=0.0034 \mathrm{~m} / \mathrm{s}$ ), whereas the velocity is an order of magnitude lower at lower permeability (groundwater velocity $=3.4 \times 10^{-5} \mathrm{~m} / \mathrm{s}$ ). The lowest velocities, which occur within the peat, are virtually unchanged amongst the three gravel beach permeability scenarios. A larger change promoted by the variation in gravel beach permeability is in the morphology of the subterra-nean estuary, which grows inland under higher permeability condi-tions and decreases dramatically at lower permeability conditions, where most of the saline water remains within the beach sediments and a slight lowering of salinity at the low-tide line signifies that a freshwater tube is forming.

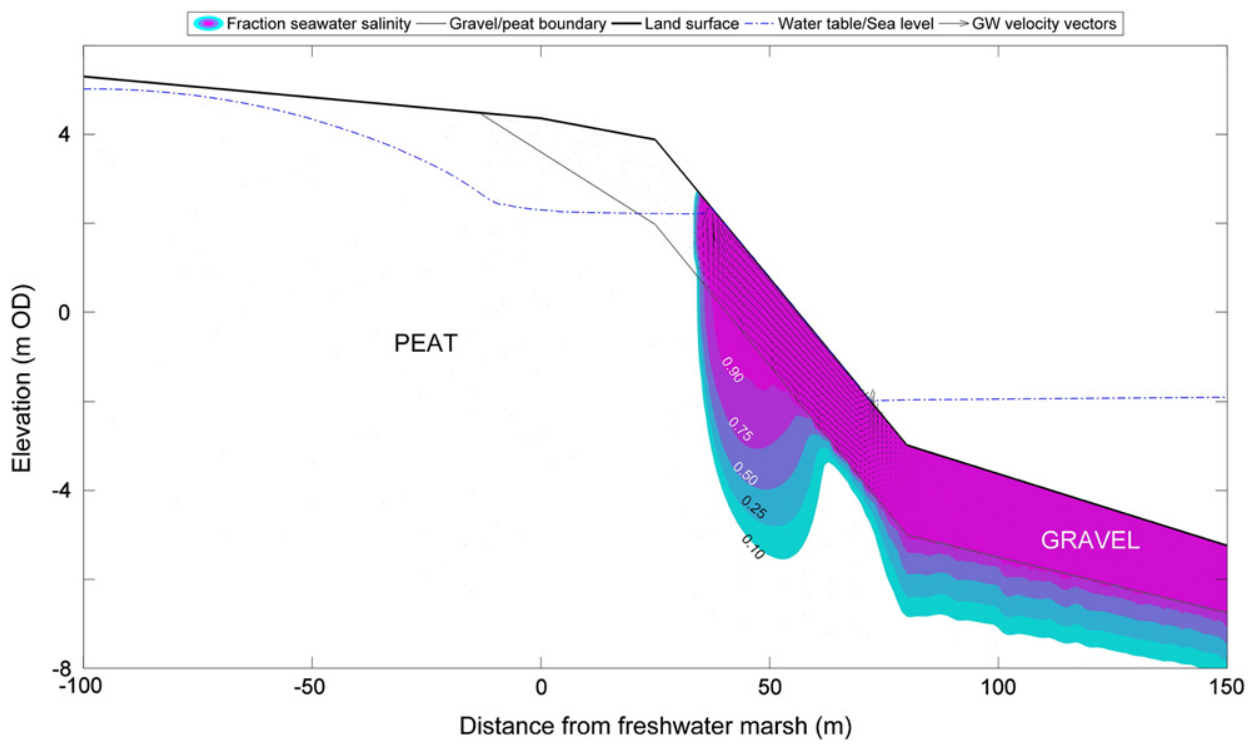

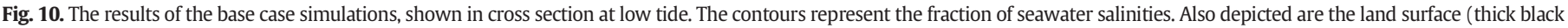

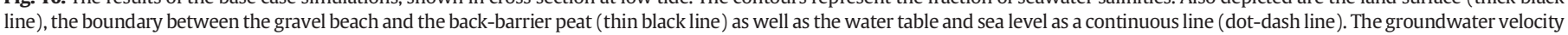
vectors, which are scaled such that the longest line represents a magnitude of $3.4 \times 10^{-4} \mathrm{~m} / \mathrm{s}$, only display in the gravel beach, where most of the groundwater circulation takes place. 


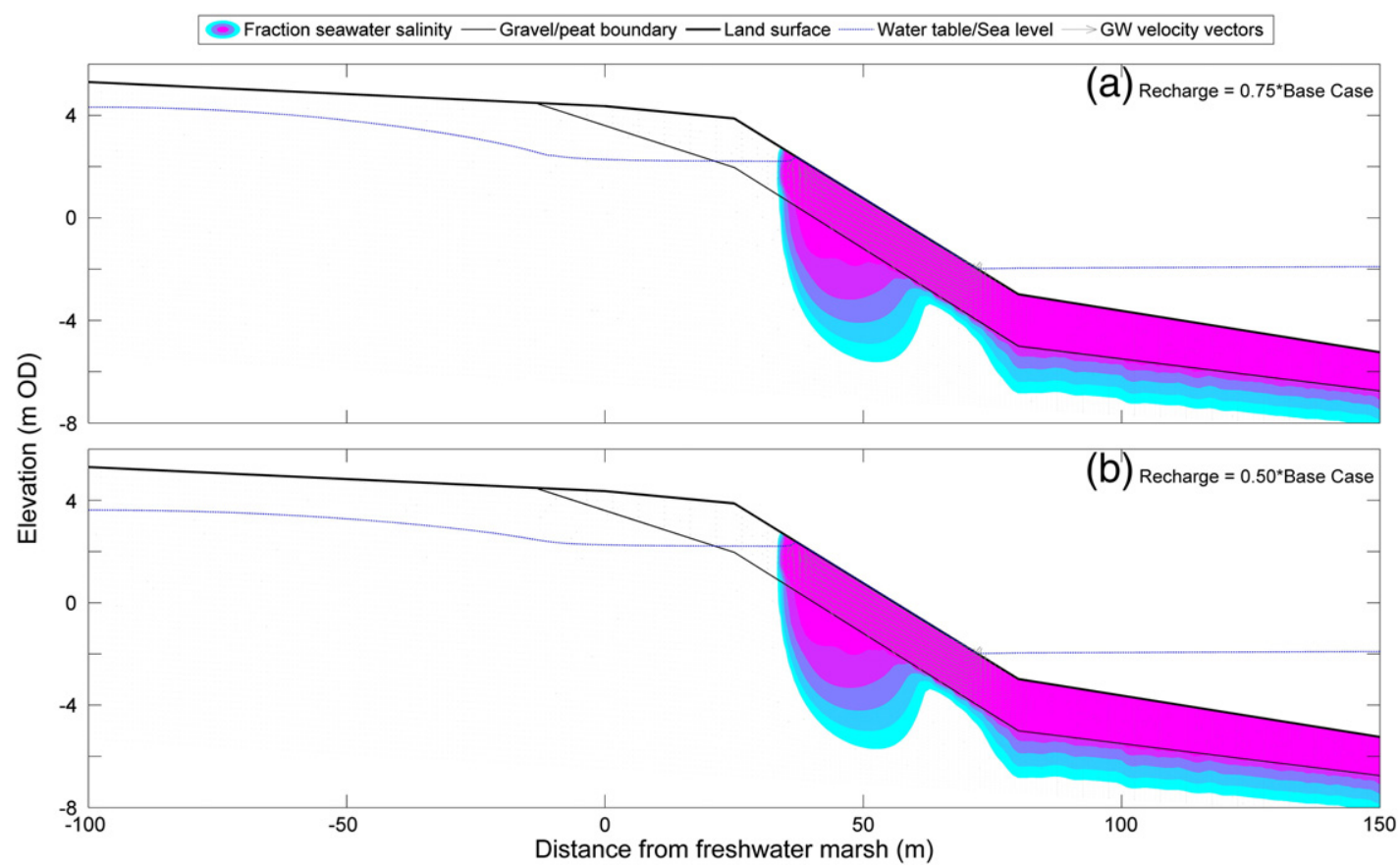

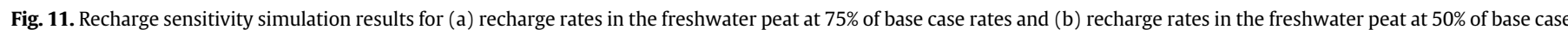
rates. The fractional seawater salinities are the same as those in Fig. 10 and, thus, are not labelled on this figure. Maximum and minimum groundwater velocities are the same as those in Fig. 10.

Simulation output is much more sensitive to changes in peat perme-ability. As with the gravel permeability, peat permeability was varied by an order of magnitude above and below the base case in order to assess the influence of the hydraulic properties of the peat on water levels in the marsh. Lowering of the peat permeability by an order of magnitude, which is not shown in Fig. 12, created significant ponding in the marsh. Raising the peat permeability by an order of magnitude, however, significantly lowered the water-table elevation in the marsh to a maximum of $2.53 \mathrm{~m}$ OD (Fig. 12c). This level, which is $2 \mathrm{~m}$ below the land surface, would facilitate oxidation of the freshwater marsh. Groundwater velocities in both units are similar to base case conditions. In terms of the subterranean estuary morphology, raising the peat per-meability allows higher salinities to penetrate farther into the peat. In addition, a small freshwater discharge tube separates the regular mixing zone from the upper saline plume. The high sensitivity of the peat per-meability suggests that the value used for the base case simulations is a
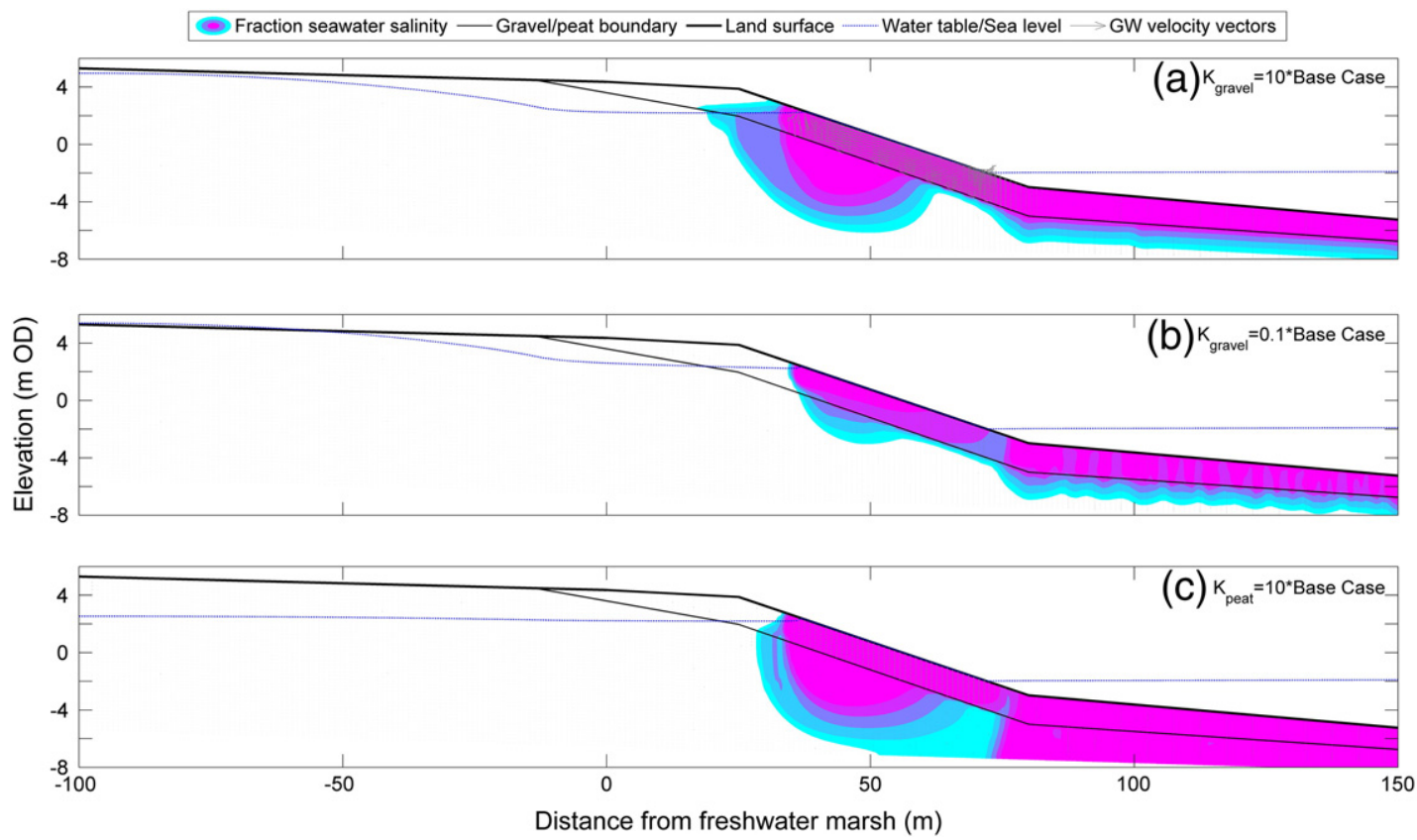

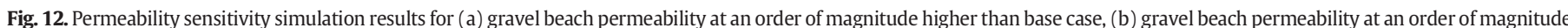

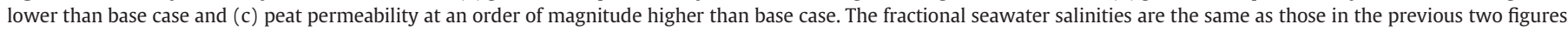

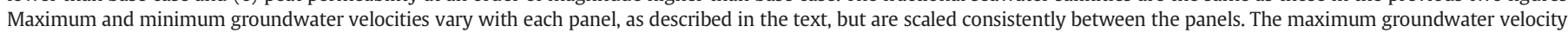
as represented by the longest vector in panel (a), is $0.0034 \mathrm{~m} / \mathrm{s}$. 


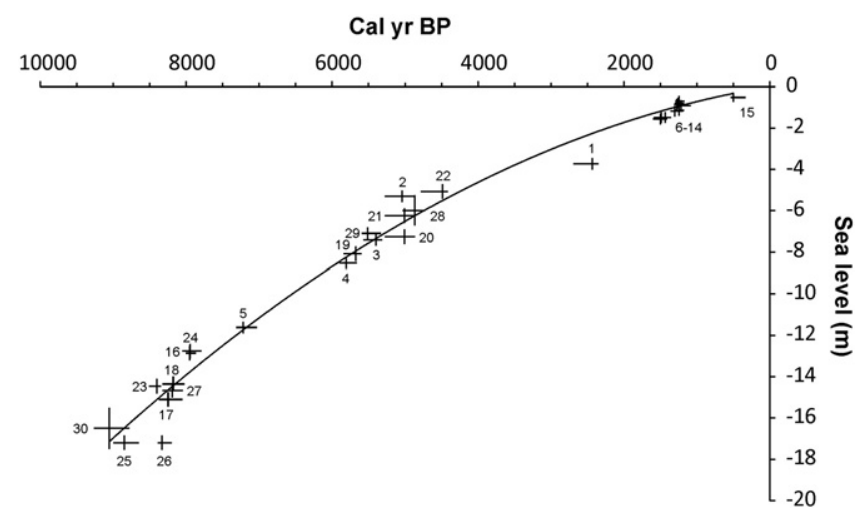

Fig. 13. Relative sea-level reconstruction for the south Devon coast. Sea-level index points are listed in Table 3. Nos. $1-5$ are the new data points from this study. The line represents a second-order polynomial fit through all data points $\left(r^{2}=0.99\right)$.

reliable and justified representation of the conditions in the peat. It should be noted that the two-dimensional simulations conducted for this study are simplified cross sections that do not take into account subtle variations in the topography of the marsh that may promote shifting environments. For example, during low-water-table conditions, alder may grow on hummocks in the marsh and reeds may replace areas formerly occupied by standing water. Oxidation of the marsh sediments may also occur during these dry episodes in addition to drying clays, which may cause enhanced recharge as cracks form macropores because of the drying process. Conversely, during high-water-table conditions, much of the marsh surface may see standing water and associated high-water deposits. These conditions have not been possible to simulate and thus the simulations should be taken as a mean condition in the marsh.

\section{Discussion}

Fig. 13 and Table 3 include the five new sea-level index points, as well as 25 previously published sea-level index points (Massey et al., 2008; Gehrels et al., 2011). We note that three new index points (nos. 2-4) are in good agreement with existing index data between 6000 and 4000 years old derived from salt-marsh deposits. Our youngest (no. 1) and oldest (no. 5) index points usefully fill gaps in the existing dataset between 8000 and 6000 cal yr BP and 4000 and 2000 cal yr BP, respectively. Our estimated error for palaeosea-level positions is $\pm 0.28 \mathrm{~m}$. An uncertainty of $\pm 0.10 \mathrm{~m}$ accounts for modelling uncertainties and for the uncertainty associated with the linear extrapolation of the groundwater gradients. The facies adjustment (see Section 4.3) accounts for $\pm 0.20 \mathrm{~m}$ uncertainty. These uncertainties are added to the standard deviation on the measurements of the modern day groundwater gradient $(0.04 \mathrm{~m})$. The sum of the errors $( \pm 0.28 \mathrm{~m})$ is calculated from the square root of the sum of the squared individual errors (cf. Shennan et al., 2006). As stated before, all index points are from basal Holocene deposits and therefore not affected by compaction.

The groundwater modelling supports the use of fossil freshwater marsh material for the development of sea-level index points. First, the base case simulation shows that the freshwater marsh develops well inland of semi-diurnal tidal variations. Although storm events may send saline water to the marsh, it is likely that the relatively high recharge rate coupled with the highly permeable gravel will facilitate removal of thesalinewaterfrom the marsh (Austin et al., 2013). Second, the simulat-ed groundwater gradient at the landward edge of the model domain, which is most representative of the position of the sampled marsh material at the time of deposition, is of the same order of magnitude as the field data suggest. Third, the dramatic differences between the base case simulation and the peat-permeability and recharge-sensitivity simulations suggest that these parameters are well constrained, thus lending credence to our new methodology.

As a further test of the viability of the methodology, we ran a simulation to determine the rapidity of water-table recovery to changes in water levels in the back-barrier marsh. In this simple scenario, we eliminated recharge in the marsh and set a constant-pressure boundary condition that set water levels in the marsh at the la $\mathrm{nd}-\mathrm{surf}$ a ce e levation. We s i m- ulated this condition for six months. At the end of this high-stand water-level condition, we returned to the recharge scenario of the base case sim-ulations. Water-table oscillations as measured in synthetic monitoring wells are shown in Fig. 14. The plot shows water-table time series for three monitoring locations, one at the rear of the simulation (horizontal

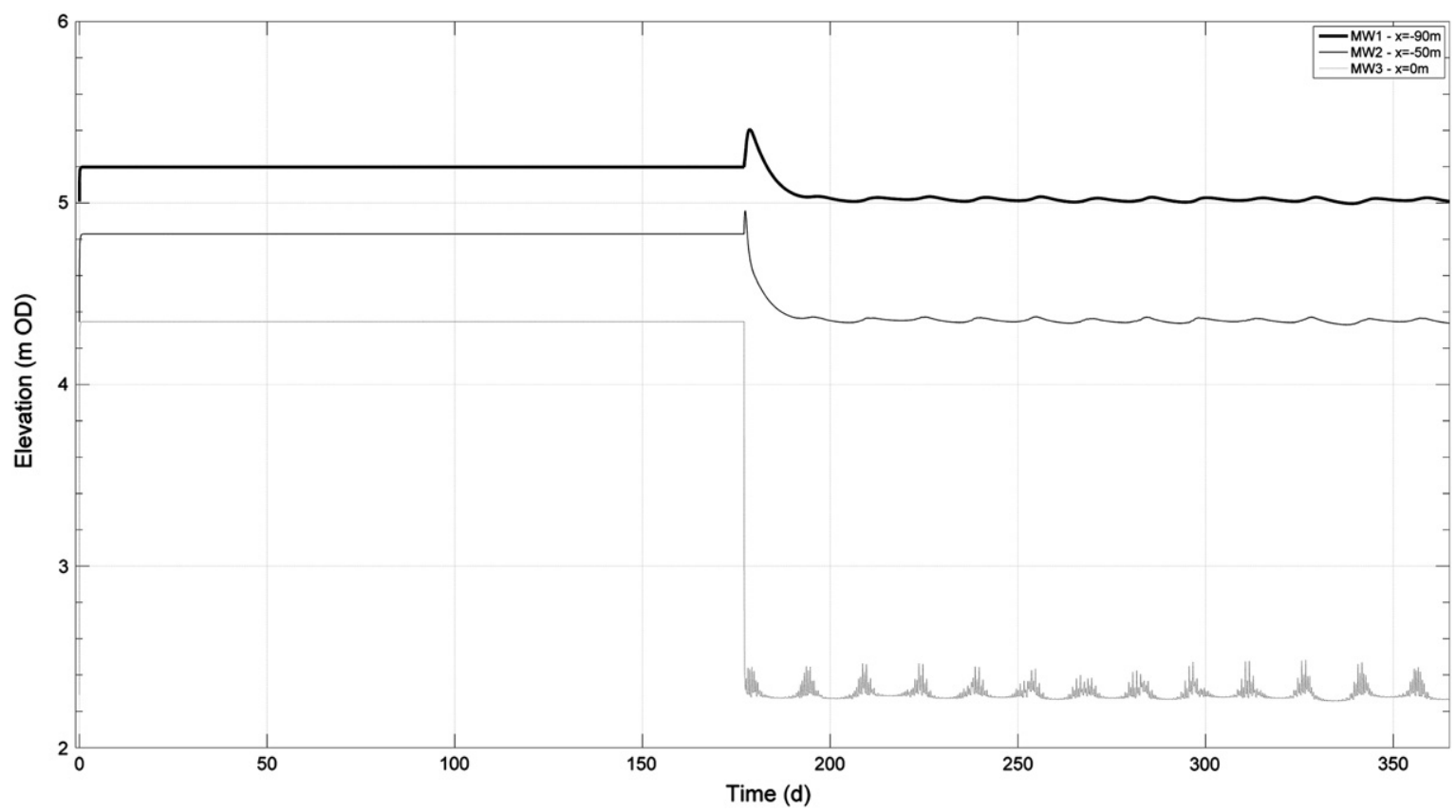

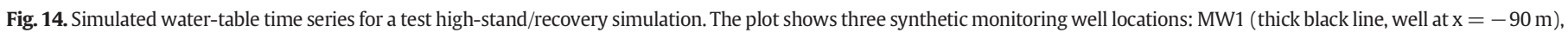
MW2 (thin black line, well at $\mathrm{x}=-50 \mathrm{~m}$ ), and MW3 (grey line, well at $\mathrm{x}=0 \mathrm{~m}$ ). 
Table 3

Holocene sea-level index points for south Devon, England (Fig. 13).

\begin{tabular}{|c|c|c|c|c|c|c|c|c|c|c|}
\hline Index no. & ${ }^{14} \mathrm{C}$ Lab. no. & Height (m OD) & Indicative meaning (m OD) & Compaction (m) & ${ }^{14} \mathrm{C}$ age $(\mathrm{yr} \mathrm{BP} \pm 1 \sigma)$ & Median age (Cal. yr BP) & 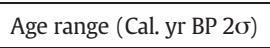 & RSL (m OD) & Type & Reference \\
\hline 1 & Beta-301961 & 1.28 & $5.03 \pm 0.28$ & 0.00 & $2410 \pm 30$ & 2432 & $2348-2689$ & $-3.74 \pm 0.14$ & B & This study \\
\hline 2 & Beta-301962 & -0.56 & $4.74 \pm 0.28$ & 0.00 & $4440 \pm 30$ & 5041 & $4880-5279$ & $-5.30 \pm 0.14$ & B & This study \\
\hline 3 & Beta-301963 & -2.35 & $5.26 \pm 0.28$ & 0.00 & $4670 \pm 30$ & 5399 & $5316-5568$ & $-7.61 \pm 0.14$ & B & This study \\
\hline 4 & Beta-301964 & -3.20 & $5.32 \pm 0.28$ & 0.00 & $5040 \pm 40$ & 5810 & 5663-5902 & $-8.52 \pm 0.14$ & B & This study \\
\hline 5 & Beta-292531 & -6.05 & $5.56 \pm 0.28$ & 0.00 & $6290 \pm 40$ & 7218 & $7034-7316$ & $-11.62 \pm 0.14$ & B & This study \\
\hline 6 & SUERC-20170 & 1.37 & $2.31 \pm 0.20$ & 0.03 & $1321 \pm 35$ & 1260 & $1178-1300$ & $-0.80 \pm 0.26$ & B & Gehrels et al., 2011 \\
\hline 7 & SUERC-20041 & 1.04 & $2.31 \pm 0.20$ & 0.02 & $1310 \pm 35$ & 1248 & $1178-1294$ & $-1.14 \pm 0.26$ & B & Gehrels et al., 2011 \\
\hline 8 & SUERC-20171 & 1.10 & $2.41 \pm 0.20$ & 0.01 & $1385 \pm 37$ & 1303 & $1193-1363$ & $-1.19 \pm 0.26$ & B & Gehrels et al., 2011 \\
\hline 9 & SUERC-20172 & 1.47 & $2.31 \pm 0.20$ & 0.03 & $1306 \pm 37$ & 1243 & $1175-1296$ & $-0.70 \pm 0.26$ & B & Gehrels et al., 2011 \\
\hline 10 & SUERC-20173 & 1.40 & $2.41 \pm 0.20$ & 0.05 & $1342 \pm 37$ & 1277 & $1178-1313$ & $-0.85 \pm 0.26$ & B & Gehrels et al., 2011 \\
\hline 11 & SUERC-20174 & 1.34 & $2.41 \pm 0.20$ & 0.05 & $1270 \pm 37$ & 1216 & $1087-1287$ & $-0.91 \pm 0.26$ & B & Gehrels et al., 2011 \\
\hline 12 & SUERC-20175 & 0.78 & $2.41 \pm 0.20$ & 0.02 & $1539 \pm 35$ & 1437 & $1354-1521$ & $-1.50 \pm 0.26$ & B & Gehrels et al., 2011 \\
\hline 13 & SUERC-23074 & 0.70 & $2.31 \pm 0.20$ & 0.01 & $1610 \pm 35$ & 1486 & $1406-1591$ & $-1.49 \pm 0.26$ & B & Gehrels et al., 2011 \\
\hline 14 & SUERC-23075 & 0.63 & $2.31 \pm 0.20$ & 0.01 & $1619 \pm 35$ & 1501 & $1410-1600$ & $-1.56 \pm 0.26$ & B & Gehrels et al., 2011 \\
\hline 15 & SUERC-23081 & 2.08 & $2.76 \pm 0.15$ & 0.05 & $439 \pm 35$ & 502 & $335-536$ & $-0.52 \pm 0.21$ & B & Gehrels et al., 2011 \\
\hline 16 & AA-38822 & -13.68 & $-0.88 \pm 0.29$ & 0.01 & $7119 \pm 63$ & 7946 & $7792-8049$ & $-12.76 \pm 0.35$ & B & Massey et al., 2008 \\
\hline 17 & AA-38823 & -13.10 & $2.28 \pm 0.29$ & 0.19 & $7408 \pm 59$ & 8247 & $8050-8371$ & $-15.10 \pm 0.35$ & B & Massey et al., 2008 \\
\hline 18 & AA-38824 & -12.80 & $1.91 \pm 0.29$ & 0.27 & $7359 \pm 59$ & 8176 & $8029-8323$ & $-14.35 \pm 0.35$ & I & Massey et al., 2008 \\
\hline 19 & CAMS-75525 & -5.74 & $2.47 \pm 0.29$ & 0.02 & $4949 \pm 40$ & 5676 & $5596-5842$ & $-8.08 \pm 0.35$ & B & Massey et al., 2008 \\
\hline 20 & CAMS-75526 & -5.00 & $2.57 \pm 0.29$ & 0.21 & $4420 \pm 40$ & 5007 & $4867-5276$ & $-7.25 \pm 0.35$ & I & Massey et al., 2008 \\
\hline 21 & CAMS-75529 & -4.43 & $2.27 \pm 0.29$ & 0.35 & $4420 \pm 40$ & 5007 & $4867-5276$ & $-6.24 \pm 0.35$ & I & Massey et al., 2008 \\
\hline 22 & CAMS-75530 & -3.34 & $2.33 \pm 0.29$ & 0.49 & $4020 \pm 40$ & 4487 & $4414-4782$ & $-5.07 \pm 0.35$ & I & Massey et al., 2008 \\
\hline 23 & CAMS-75518 & -11.95 & $2.62 \pm 0.29$ & 0.00 & $7600 \pm 40$ & 8402 & $8343-8508$ & $-14.46 \pm 0.35$ & B & Massey et al., 2008 \\
\hline 24 & CAMS-75519 & -12.45 & $0.52 \pm 0.29$ & 0.00 & $7120 \pm 30$ & 7953 & $7870-8006$ & $-12.86 \pm 0.35$ & B & Massey et al., 2008 \\
\hline 25 & CAMS-72401 & -14.76 & $2.55 \pm 0.29$ & 0.00 & $7980 \pm 50$ & 8850 & $8648-9000$ & $-17.19 \pm 0.35$ & B & Massey et al., 2008 \\
\hline 26 & CAMS-72402 & -14.76 & $2.55 \pm 0.29$ & 0.00 & $7500 \pm 40$ & 8331 & $8201-8390$ & $-17.19 \pm 0.35$ & B & Massey et al., 2008 \\
\hline 27 & CAMS-75531 & -12.21 & $2.57 \pm 0.29$ & 0.00 & $7370 \pm 40$ & 8192 & $8045-8321$ & $-14.66 \pm 0.35$ & B & Massey et al., 2008 \\
\hline 28 & SRR164 & -4.32 & $\mathrm{n} / \mathrm{a}$ & $\mathrm{n} / \mathrm{a}$ & $4302 \pm 45$ & 4870 & $4729-5034$ & $-5.99 \pm 0.73$ & I & Hails, 1975 \\
\hline 29 & SRR165 & -4.62 & $\mathrm{n} / \mathrm{a}$ & $\mathrm{n} / \mathrm{a}$ & $4767 \pm 45$ & 5512 & 5328-5594 & $-7.09 \pm 0.29$ & I & Hails, 1975 \\
\hline 30 & SRR237 & -16.50 & $\mathrm{n} / \mathrm{a}$ & $\mathrm{n} / \mathrm{a}$ & $8108 \pm 60$ & 9056 & $8779-9265$ & $-16.50 \pm 1.00$ & $\mathrm{~L}$ & Hails, 1975 \\
\hline
\end{tabular}

RSL - relative sea level. OD - Ordnance Datum. B - basal. I - intercalated. L - limiting. 


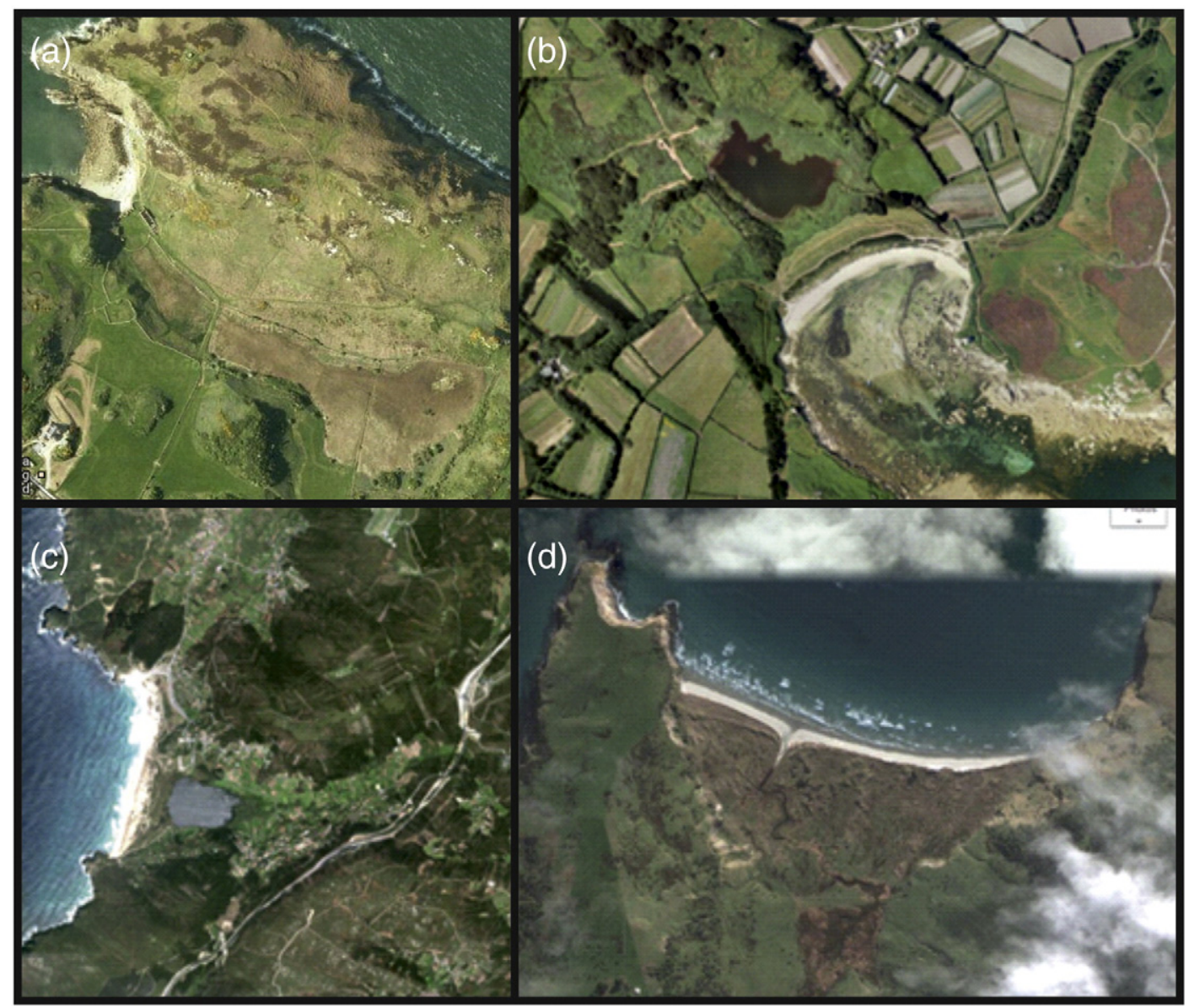

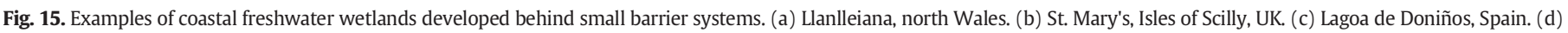
Heyward Point, South Island, New Zealand. Images from Google Earth.

position of $-90 \mathrm{~m})$, one in the middle of the marsh $(-50 \mathrm{~m})$, and one at the front of the marsh that is completed in gravel $(0 \mathrm{~m})$. Several things are of note in these simulations. First, water-table elevations show instantaneous response to the rise in the conditions at the surface, and this increased gradient removes a tidal signal that was previously able to penetrate the aquifer. After six months, the simulation returns to base case recharge patterns. After a short adjustment in water levels to reflect saturated conditions and the addition of a further source of water, watertable elevations in the monitoring wells return to the pre-high-stand conditions within approximately ten days. Note also that the tidal signal, in response to the return of the lower gradient, once again appears in the signal, especially in the gravel location, where the spring/neap cycle is evident. The rapid recovery rate of simulated groundwater levels to changes in boundary conditions further demonstrates that freshwater peats in settings such as the Hallsands field site provide a reliable proxy for sea level.

It is interesting to note that the first systematic Holocene sea-level reconstructions from western Europe in the 1950s and 1960s were also based on freshwater peat. Bennema (1954) and Jelgersma (1961) were the firsts to argue that the basal peat in the coastal deltaic plain of the Netherlands was formed under groundwater conditions that were directly controlled by Holocene sea-level rise. The upper limit of coastal peat formation in backbarrier lagoons in the Netherlands was considered to occur above mean sea level (Jelgersma, 1961) or close to mean high water (MHW) (van de Plassche, 1982), whilst the lower limit was considered to be below MHW or mean high water of spring tides (Kiden et al., 2002). The exact level of peat growth is difficult to determine because of the dampening of the tidal range away from tidal inlets and therefore demands detailed knowledge of palaeogeography (Vis et al., submitted for publication). Interpreting the groundwater history in terms of changes in sea level requires the unravelling of local palaeotidal changes and what is known in the sea-level literature as the 'river-gradient effect', i.e.thegradient of the water table in coastal deltas (Louwe Kooijmans, 1974; van de Plassche, 1980). An important consideration is also the nature and permeability of the underlying substrate because well-drained substrates prevent local peat formation in ponds decoupled from sea level (van de Plassche, 1981).

The scale of deltas creates groundwater gradients of only several centimetres per kilometre (van de Plassche et al., 2010), an order of magnitude less than in the back-barrier system of Hallsands, but deltas have complex palaeogeographies. Determination of the effects of palaeotidal-range changes and river gradients is crucial to the inter-pretation of the sea-level history (e.g. Hijma and Cohen, 2011; Makaske and Hoek, 2011) and depends on the configuration of barrier complexes and the timing of their formation (Vis et al., submitted for publication). The clear advantage of a small system such as Hallsands is that the groundwater-sea level relationship is much simpler. Nonetheless, the application of groundwater modelling may be beneficial to deltaic areas.

We note that small coastal barriers and associated peatlands without an open-water connection to the sea are common along many coastlines. These settings have been an untapped resource for the reconstruction of Holocene sea-level changes and our study demonstrates that the freshwater peat that has accumulated behind the barriers forms a valuable sea-level archive. In Fig. 15 we show examples of barrierpeat systems from around the world where basal peats may provide reliable sea-level index points. 


\section{Conclusions}

The base of Holocene freshwater peat sequences in small back-barrier systems provides reliable index points for the reconstruction of relative Holocene sea-level changes, provided that the following conditions are met:

1. The back-barrier stratigraphy shows uninterrupted peat sequences that demonstrate that the barrier has remained closed throughout the history of peat accumulation and that processes that instigate reworking of peat (e.g. creek bank erosion) have been insignificant.

2. Field and modelling evidence shows that the influence of sea level on the back-barrier water table is strong and rapid enough to overprint climate-controlled variability.

3. Values of recharge and peat permeability are within the limits that prevent ponding or drying out of the back-barrier marsh and are the primary control on the water table in the back-barrier marsh.

4. The beach is relatively thin and its permeability is not the main control on the elevation of the water table in the back-barrier marsh.

All these conditions are met at Hallsands and five new sea-level index points were added to the regional sea-level curve for the Channel coast of south Devon, England. Investigations from similar settings elsewhere could add significantly to the global database of Holocene sea-level index points. 